\title{
THE 3' END PROTHROMBIN GENE VARIANTS IN SERBIAN PATIENTS WITH IDIOPATHIC THROMBOPHILIA
}

\author{
Aradjanski $\mathrm{M}^{1}$, Djordjevic $\mathrm{V}^{1}$, Pruner $\mathrm{I}^{1, *}$, Tomic B ${ }^{1}$, Gvozdenov $\mathrm{M}^{1}$, Kovac $\mathrm{M}^{2,3}$, Radojkovic $\mathrm{D}^{1}$
}

\begin{abstract}
*Corresponding Author: Dr. Iva Pruner, Institute of Molecular Genetics and Genetic Engineering, Vojvode Stepe 444A, PO Box 23, 11010 Belgrade, Serbia. Tel: +381-11-397-6658. Fax: +381-11-397-5808. E-mail: iva.pruner@, gmail.com
\end{abstract}

\begin{abstract}
Thrombophilia is a multifactorial disorder that arises from the interaction of acquired and genetic risk factors. Despite the significant efforts made to understand the etiology of this disease, there are still a certain number of patients suffering from idiopathic thrombophilia. The aim of this study was to screen the 3' end of the prothrombin (FII) gene, which is susceptible to gain-of-function mutations due to its non canonical architecture, in patients with idiopathic thrombophilia and to determine its eventual role in the pathogenesis of thrombophilia.

This study was carried out in 100 patients with idiopathic thrombophilia and 100 healthy controls. DNA variants in the $715 \mathrm{bp}$ long region of the 3 ' end of the prothrombin gene were identified by sequencing. In our study, we detected two variants: A19911G and C20068T. The frequency of the $A 19911 G$ gene variant was slightly increased in the group of patients compared to controls, however with no statistically significant difference compared to controls [odds ratio $(\mathrm{OR})=1.06 ; 95 \%$ confidence interval $(95 \%$ CI) 0.53-2.13]. Heterozygous carriers of the FII C20068T gene variant were four times more frequent in patients $(4.0 \%)$ than in controls $(1.0 \%)$, but this
\end{abstract}

\footnotetext{
${ }^{1}$ Institute of Molecular Genetics and Genetic Engineering, University of Belgrade, Belgrade, Serbia

${ }^{2}$ Faculty of Medicine, University of Belgrade, Serbia

${ }^{3}$ Blood Transfusion Institute of Serbia, Hemostasis Department, Belgrade, Serbia
}

difference did not reach statistical significance (OR $=4.12$; $95 \%$ CI $0.45-37.57$ ). Our findings suggest that variant A $19911 \mathrm{G}$ is not a significant risk factor, while C20068T may represent a potential risk factor for idiopathic thrombophilia. To confirm our results, further studies should be conducted in a larger cohort of patients.

Keywords: 3' End prothrombin (FII) gene; Gene variants; Thrombophilia

\section{INTRODUCTION}

Thrombophilia refers to a group of inherited or acquired coagulation disorders, leading to venous and/or arterial thrombosis. The most frequent clinical manifestations of venous thrombosis are deep vein thrombosis (DVT), pulmonary embolism (PE) and in case of obstruction of placental circulation, fetal loss (FL). Arterial thrombosis can manifest as myocardial infarction (MI), ischaemic stroke or arterial embolism [1].

Thrombophilia is a multifactorial disorder that arises from the interaction of acquired and genetic risk factors [2]. The most common acquired risk factors include surgery, immobilization, fractures, puerperium, paralysis, prolonged bed rest and use of oral contraceptives [3] The most important genetic risk factors contributing to thrombophilia are deficiencies of natural inhibitors of clotting factors (antithrombin, protein C, protein S), Factor V Leiden (FVL) mutation and prothrombin (FII) G20210A mutation. Deficiencies of natural inhibitors occur sparsely, but rep- 
resent significant risk factor [4-9]. The FVL mutation is present $3.0-7.0 \%$ in Caucasians and $15.0-50.0 \%$ in patients with thrombosis, while the incidence of FII G20210A is $1.0-2.0 \%$ in Caucasian populations and $18.0-20.0 \%$ in patients with thrombosis [8].

The FVL mutation yields an amino acid substitution within the cleavage site of its inhibitor-activated protein $\mathrm{C}$ that results in impaired inhibition of $\mathrm{FV}$ and increased thrombin generation leading to hypercoagubility [10-12].

The FII G20210A gene variant is located in the 3' untranslated region (3'UTR) of the FII gene and it has been associated with elevated plasma FII levels. This is a gain-of-function mutation, causing increased cleavage site recognition and 3' end mRNA processing, which leads to an increased FII synthesis [1316]. Apart from the FII G20210A, several variants have been detected in the 3 ' end of the FII gene, such as: A19911G, C20211T, T20219A, A20218G and $C 20209 T$ [17-25].

The 3' end of the FII gene is a dynamic region because of its non canonical architecture, therefore, it could be a potential region for finding new variants which might contribute to thrombophilia [13-15]. Despite the fact that several genetic risk factors have been associated with thrombophilia, there are still a certain number of patients suffering from idiopathic thrombophilia, defined as unequivocal clinical picture of thrombosis with unknown risk factors. Additionally, there are no data regarding the frequency of FII 3' end gene variants in patients with idiopathic thrombophilia in Serbia. The aim of this study was to screen 3 ' end of $F I I$ gene in population of patients with idiopathic thrombophilia originating from the geographic area of Serbia.

\section{MATERIALS AND METHODS}

Patients. The study group was formed by searching the database of over 4000 patients who were referred to the Institute of Molecular Genetics and Genetic Engineering, University of Belgrade, Belgrade, Serbia for genetic testing of thrombophilia during the period from 2000 to 2013. Anamnestic data were gathered from all the participants and the following subjects were excluded from further investigation: the patients who developed the first thrombotic event at an age above 50 years, the patients with malignancies, diabetes, antiphospholipid antibodies, deficiency of natural inhibitors (antithrombin, protein $\mathrm{C}$, protein S), and the carriers of FVL and FII G20210A gene mutations [26]. Finally, the study group included 100 patients (age range 16-63, median 38 years; male/ female: 45/55) with a clinical picture of recurrent thrombotic events (DVT, PE, FL) or the combination of two or three thrombotic events (DVT, PE, FL, MI and stroke).

The control group comprised 100 healthy subjects (age range: 20-66 years, median 39; male/female: $82 / 18$ ) with no history of thrombotic events. Informed consent was obtained from all participants and the study protocol was approved by the local research ethics committee.

Laboratory Methods. Peripheral blood was taken on $3.8 \%$ sodium citrate as anticoagulant. Genomic DNA was purified from $200 \mu \mathrm{L}$ of human whole blood using the QIAamp DNA blood mini kit (Qiagen GmbH, Hilden, Germany) according to the manufacturer's protocol. The blood and DNA samples were stored at $-20^{\circ} \mathrm{C}$ until further use.

The $715 \mathrm{bp}$ fragment that includes the last intron and exon, 3'UTR and the flanking region of the FII gene (primers: 5'-GGA AAC GAG GGG ATG CCT GT-3' and 5'-CCT GCC ATC TTT CCT CTC AC-3'), was amplified by polymerase chain reaction (PCR). The PCR reactions were performed in a $25 \mu \mathrm{L}$ final volume: $1 \times$ Kapa Buffer B; $2.5 \mathrm{mM} \mathrm{MgCl}_{2} ; 200 \mu \mathrm{M}$ dNTPs; 1U Kapa Taq polymerase (Kapa Biosystems, Boston, MA, USA), 10 pmol of forward and reverse primers and 200 ng of DNA. The thermal cycle profile was: initial denaturation at $95{ }^{\circ} \mathrm{C}$ for $5 \mathrm{~min}$. and 37 cycles consisting of denaturation at $95^{\circ} \mathrm{C}$ for $1 \mathrm{~min}$., annealing at $61{ }^{\circ} \mathrm{C}$ for $1 \mathrm{~min}$. and polymerization at $72{ }^{\circ} \mathrm{C}$ for $1 \mathrm{~min}$. were applied. Final extension of the PCR products was at $72{ }^{\circ} \mathrm{C}$ for $10 \mathrm{~min}$.

Sequencing of the amplified $715 \mathrm{bp}$ fragments was performed according to the manufacturer's protocol, using the BigDye ${ }^{\mathrm{TM}}$ Terminator Version 3.1 Ready Reaction Kit (Applied Biosystems, Foster City, CA, USA) on a 3130 Genetic Analyzer (Applied Biosystems). Two sequencing reactions for the fragment of interest were performed for each sample using the forward primer (5'-TCT AGA AAC AGT TGC CTG GC-3') or reverse primer (5'-GAA TAG CAC TGG GAG CAT TGA-3').

Statistical Analysis. Statistical analysis was performed using MedCalc 12.2.1.0 statistical software (MedCalc Software bvba, Ostend, Belgium). The 
prevalence of detected gene variants was compared between patients and controls with the use of Fisher's exact test. The odds ratio (OR) and 95\% CI (95\% confidence interval) were also estimated. A $p$ value of $<0.05$ was considered to be statistically significant. Deviations of genotype distributions from HardyWeinberg equilibrium were assessed by the $\mathrm{c}^{2}$-test.

\section{RESULTS}

In this study, we included 100 patients with idiopathic thrombophilia and 100 healthy controls. The clinical data of the study group are shown in Table 1. In our study, we detected the presence of A19911G and C20068T variants in the 3' end of the FII gene (Figure 1).

In the patient group, there were $51.0 \%$ heterozygous and $20.0 \%$ homozygous carriers of the $\mathrm{A} 19911 \mathrm{G}$ variant, which was similar to the frequency in the control group $(51.0 \%$ heterozygous and $19.0 \%$ homozygous) (Table 2). The results of our study showed that the difference between patients and controls was not statistically significant $(p=0.88)$ and that A19911G does not represent a risk factor for idiopathic thrombophilia in our study $(\mathrm{OR}=1.06 ; 95 \%$ CI $0.53-2.13)$. Regarding this variant, both groups were in HardyWeinberg equilibrium $\left(\mathrm{c}^{2}=0.08 ; p=0.77\right)$.

The $\mathrm{C} 20068 \mathrm{~T}$ variant was detected only in the heterozygous state, with frequencies of $4.0 \%$ in patients and $1.0 \%$ in the control group (Table 2). Even though this difference between patients and controls was not statistically significant ( $p=0.21$ ), it could represent a risk factor in idiopathic thrombophilia $(\mathrm{OR}=4.12 ; 95 \% \mathrm{CI} 0.45-37.52)$. The study groups were in Hardy-Weinberg equilibrium for this variant $\left(c^{2}=0.04 ; p=0.83\right)$.

In our study, $4.0 \%$ of the patients were carriers of both A19911G and C20068T mutations. This subset of patients was distinguished by more severe thrombotic manifestations. In one, DVT reoccurred six times and three patients suffered from the combination of more than two thrombotic events (MI, DVT, PE, FL, and stroke).

\section{DISCUSSION}

In order to identify potential thrombophilic risk factors in these patients, we chose to sequence the 3 ' end of the FII gene, since it has been shown that this region is very susceptible to gain-of-function mutations [13-15]. We detected two variants in the 3' end of the FII gene, $A 19911 G$ and C20068T, in both the patients and control groups.

The $A 19911 G$ gene mutation is located in the last intron of the FII gene and functional analyses showed that the presence of this variant enhances splicing efficiency by altering a known functional pentamer motif [24]. In our study, the frequency of the $A 19911 G$ gene variant in patients was similar to the frequencies in the control group. The frequency of the $G$ allele in our study was 0.44 , which is very similar to the frequencies that were reported for throm-

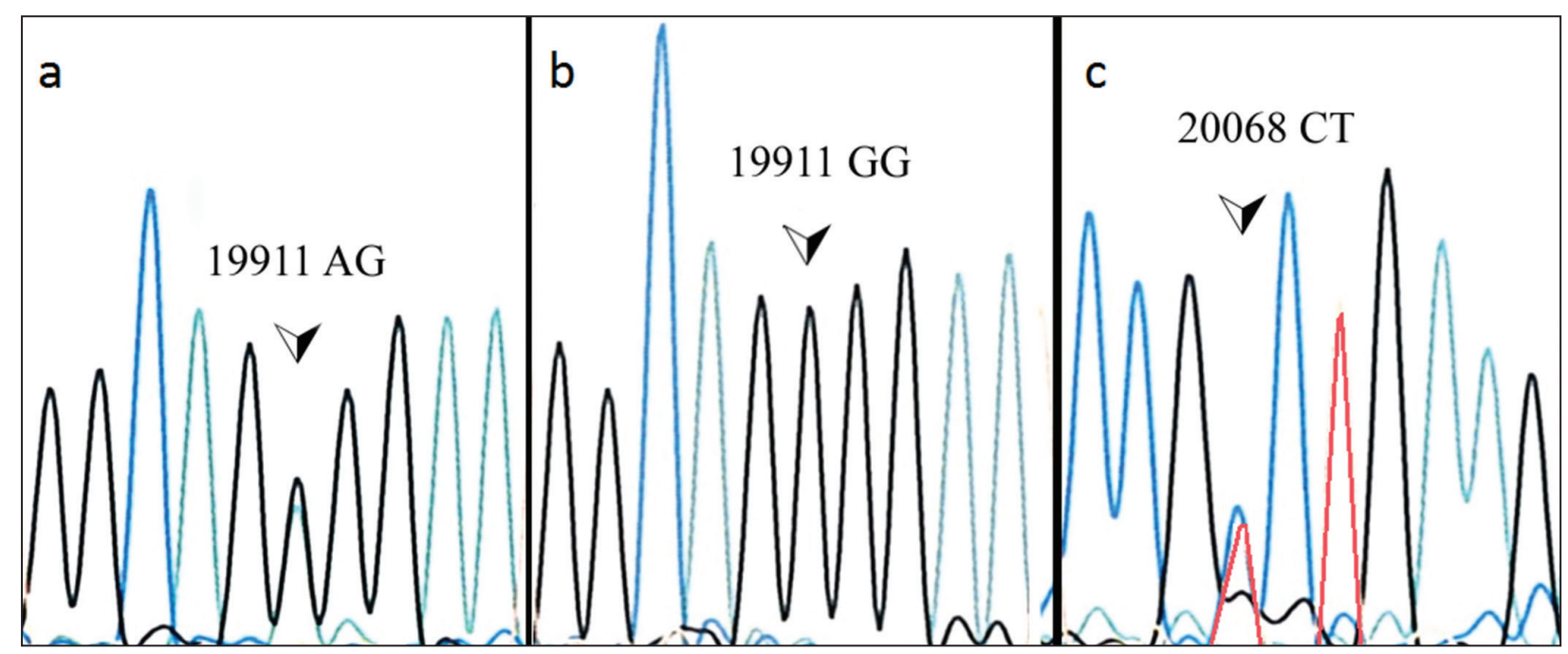

Figure 1. Part of the FII gene sequence with: a) the FII A19911G gene variant in heterozygous state; b) the FII A19911G gene variant in homozygous state; c) the FII C20068T gene variant in heterozygous state. 
Table 1. Data of the Patients.

\begin{tabular}{|l|c|c|c|}
\hline Thrombotic Event & $\begin{array}{c}\text { Number of } \\
\text { Patients }\end{array}$ & Male/Female & $\begin{array}{c}\text { Age Range } \\
\text { (median) }\end{array}$ \\
\hline Recurrent DVT & 50 & $26 / 24$ & $16-63(39)$ \\
\hline Recurrent PE & 6 & $3 / 3$ & $25-41(36)$ \\
\hline Recurrent FL & 4 & $0 / 4$ & $29-41(35.5)$ \\
\hline Combination of thrombotic events (DVT, PE, FL, MI, stroke) & 40 & $16 / 24$ & $19-54(38)$ \\
\hline
\end{tabular}

DVT: deep vein thrombosis; PE: pulmonary embolism; FL: fetal loss; MI: myocardial infarction.

Table 2. The frequencies of detected gene variants in the studied population.

\begin{tabular}{|l|c|c|c|}
\hline $\begin{array}{l}\text { Gene } \\
\text { Variant }\end{array}$ & $\begin{array}{c}\text { Patients/ } \\
\text { Controls }\end{array}$ & OR; 95\% CI & $\boldsymbol{p}$ Value \\
\hline A19911G & & - & \\
AG & $51 / 51$ & - & - \\
GG & $20 / 19$ & $1.06 ; 0.53-2.13$ & 0.858 \\
\hline C20068T & & & \\
CT & $4 / 1$ & $4.12 ; 0.45-37.37$ & 0.208 \\
TT & $0 / 0$ & - & - \\
\hline
\end{tabular}

bophilia patients in other populations: Italian (0.51), Spanish (0.52) and Dutch (0.48) [22-23]. According to our results, A19911G does not represent a risk factor for idiopathic thrombophilia (Table 2). A recent study by Martinelli et al. [23] that investigated the risk of cerebral sinus-venous thrombosis in patients with A19911G, also showed that this variant does not represent a significant risk factor for this thrombotic disorder. However, the MEGA study [25], which included over 5000 patients and 5000 controls showed that the presence of the $19911 \mathrm{GG}$ genotype represents 1.43-fold greater risk for thrombotic occurrence (95\% CI 1.27-1.67) compared to the 19911AA genotype.

The $C 20068 T$ gene variant is located in the last exon of the FII gene. As it does not result in a change of the amino acid sequence of a protein, it is considered as a synonymous variant. In vitro functional assays revealed that constructs with the $C 20068 T$ gene variant increased expression level 1.64 times compared to the wild type construct [27]. However, further studies are needed in order to clarify the exact mechanism of overexpression. In our study, we detected this variant only in the heterozygous state, with a higher frequency in patients than in controls. Moreover, further studies in a larger group of subjects are needed in order to elucidate the importance of this gene variant for etiology of idiopathic thrombophilia. To the best of our knowledge, there are no studies considering the prevalence of $\mathrm{C} 20068 \mathrm{~T}$ in patients with thrombophilia or any other disease.

In our study, $4.0 \%$ of the patients were carriers of a combined $20068 C T / 19911 A G$ genotype. These patients experienced more severe clinical manifestations of throm-bophilia. This result alludes to the possible role of the association of $\mathrm{C} 20068 \mathrm{~T}$ and A19911G in pathogenesis of thrombophilia. Nevertheless, functional studies are needed to yield more precise conclusions.

Other variants in the 3 ' end of the $F I I$ gene (C20211T, T20219A, A20218G and C20209T) that were reported in previous studies were not detected in our study. Our data indicate that the prevalence of these variants is less than $1.0 \%$ in the patients with idiopathic thrombophilia in a population originating from the geographic area of Serbia.

In order to obtain a well-defined group of patients with idiopathic thrombophilia, we applied very strict selection criteria as described in the Materials and Methods section, which led to a relatively small size of the patient group. Also, the results that we obtained can be attributed to the specific criteria we used.

In conclusion, our study showed the first results for the prevalence of variants at the 3' end of the FII gene in patients with idiopathic thrombophilia. These results indicate that the $A 19911 G$ gene variant is not a significant risk factor in our study group. On the other hand, the $\mathrm{C} 20068 \mathrm{~T}$ polymorphism could be a potential risk factor in idiopathic thrombophilia and therefore, further studies in a larger group of patients should be conducted.

Declaration of Interest. This study was supported by grant No. 173008 from The Ministry of Education, Science and Technological Development of 
the Republic of Serbia, Belgrade, Serbia. The authors report no conflicts of interest. The authors alone are responsible for the content and writing of this article.

\section{REFERENCES}

1. Colman RW, Clowes AW, George JN, Goldhaber SZ, Marder VJ. Overview of hemostasis. In: Colman RW, Marder VJ, Clowes AW, George JN, Goldhaber SZ. Haemostasis and Thrombosis: Basic Principles and Clinical Practice, 5th ed. Philadelphia, PA: Lippincott Wiliams \& Wilkins. 2006: 2-15.

2. White RH. The epidemiology of venous thromboembolism. Circulation. 2003; 107(23 Suppl 1): 14-18.

3. Rosendaal FR. Venous thrombosis: Prevalence and interaction of risk factors. Haemostasis. 1999; (Suppl S1): S1-S9.

4. Griffin JH, Evatt B, Wideman C. Anticoagulant protein $\mathrm{C}$ pathway defective in majority of thrombophilia patients. Blood. 1993; 82(7): 1989-1993.

5. Egeberg O. Inherited antithrombin III deficiency causing thrombophilia. Thromb Diath Haemorrh. $1965 ; 13$ : 516-530.

6. Griffin JH, Evatt B, Zimmerman TS, Kleiss AJ, Wideman C. Deficiency of protrombin C in congenital thrombotic disease. J Clin Invest. 1981; 68(5): 1370-1373.

7. Comp PC, Nixon RR, Cooper MR, Esmon CT. Familial protein $\mathrm{S}$ deficiency is associated with recurrent thrombosis. J Clin Invest. 1984; 74(6): 2082-2088.

8. Cushman M. Inherited risk factors for venous thrombosis. Hematology Am Soc Hematol Educ Program 2005: 452-457.

9. März W, Nauck M, Wieland H. The molecular mechanisms of inherited thrombophilia. Z Kardiol. 2000; 89(7): 575-586.

10. Kalafatis M, Rand MD, Mann KG. The mechanism of inactivation of human factor $\mathrm{V}$ and human factor Va by activated protein C. J Biol Chem. 1994; 269(50): 31869-318680.

11. Bertina RM, Koeleman BPC, Koster T, Rosendaal FR, Dirven RJ, de Ronde H, et al. Mutation in blood coagulation factor $\mathrm{V}$ associated with resistance to activated protein C. Nature. 1994; 369(6475): 64-66.

12. De Stefano V, Chiusolo P, Paciaroni K, Leone G. Epidemiology of factor V Leiden: Clinical implications. Semin Thromb Hemost. 1998; 24(4): 367-379.

13. Gehring NH, Frede U, Neu-Yilik G, Hundsdoerfer P, Vetter B, Hentze MW, et al. Increased efficiency of mRNA 3' end formation: a new genetic mechanism contributing to hereditary thrombophilia. Nat Genet. 2001; 28(4): 389-392.

14. Danckwardt S, Hentze MW, Kulozik AE. 3'End mRNA processing: Molecular mechanisms and implications for health and disease. EMBO J. 2008; 27(3): 482-498.

15. Danckwardt S, Gehring NH, Neu-Yilik G, Hundsdoerfer P, Pforsich M, Frede U, et al. The prothrombin 3' end formation signal reveals a unique architecture that is sensitive to thrombophilic gain-of-function mutations. Blood. 2004; 104(2): 428-435.

16. Danckwardt S, Hartmann K, Gehring NH, Hentze MW, Kulozik AE. 3' End processing of the prothrombin mRNA in thrombophilia. Acta Haematol. 2006; 115(3-4): 192-197.

17. Flaujac C, Conard J, Horellou MH, Le Flem L, Samama MM. Atypical mutations of the prothrombin gene at positions 20,209 and 20,218, and a novel mutation at position 20,219. Report on 10 patients. J Thromb Haemost. 2007; 5(5): 1064-1068.

18. Warshawsky I, Hren C, Sercia L, Shadrach B, Deitcher SR, Newton E, et al. Detection of a novel point mutation of the prothrombin gene at position 20209. Diagn Mol Pathol. 2002; 11(3): 152-156.

19. Hooper C, Roberts S, Dowling N, Austin H, Lally C, Whitsett C. The prevalence of the prothrombin gene variant C20209T in AfricanAmericans and Caucasians and lack of association with venous thromboembolism. Thromb Res. 2006; 118(6): 767-768.

20. Ceelie H, Bertina RM, van HylckamaVlieg A, Rosendaal FR, Vos HL. Polymorphisms in the prothrom-bin gene and their association with plasma prothrombin levels. Thromb Haemost. 2001; 85(6): 1066-1070. 
21. Balim Z, Kosova B, Falzon K, Bezzina Wettinger $\mathrm{S}$, Colak Y. Budd-Chiari syndrome in a patient heterozygous for the point mutation C20221T of the prothrombin gene. J Thromb Haemost. 2003; 1(4): 852-853.

22. Pérez-Ceballos E, Corral J, Alberca I, Vayá A, Llamas P, Montes R, et al. Prothrombin A19911G and G20210A polymorphisms' role in thrombosis. J Haematol. 2002; 118(2): 610-614.

23. Martinelli I, Battaglioli T, Tosetto A, Legnani C, Sottile L, Ghiotto R, et al. Prothrombin A19911G polymorphism and the risk of venous thromboembolism. J Tromb Haemost. 2006; 4(12): 25822586.

24. von Ahsen N, Oellerich M. The intronic prothrombin $19911 \mathrm{~A}>\mathrm{G}$ polymorphism influences splicing efficiency and modulates effects of the $20210 \mathrm{G}>\mathrm{A}$ polymorphism on mRNA amount and expression in a stable reporter gene assay system. Blood. 2004; 103(2): 586-593.
25. Chinthammitr Y, Vos HL, Rosendaal FR, Doggen CJ. The association of prothrombin A19911G polymorphism with plasma prothrombin activity and venous thrombosis: results of the MEGA study, a large popula-tion-based case-control study. J Thromb Haemost. 2006; 4(12): 2587-2592.

26. Souto JC, Almasy L, Borrell M, Blanco-Vaca F, Mateo J, Soria JM, et al. Genetic susceptibility to thrombosis and its relationship to physiological risk factors: the GAIT study. Genetic analysis of idiopathic thrombophilia. Am J Hum Genet. 2000; 67(6): 1452-1459.

27. Djordjevic V, Pruner I, Kovac M, Miljic P, Antonijevic N, Kojic S, et al. Three novel 3' end pro-thrombin gene polymorphisms and their association with thrombophilia (abstract). J Thromb Haemost. 2011; 9(Suppl 2): 873S. 